\title{
Synthesis Characterization and Biological Activities of an Enamine Derivative and Its Coordination Compounds
}

\author{
Temitayo Aiyelabola1 ${ }^{*}$, Johannes Jordaan², Daniel Otto², Ezekiel Akinkunmi ${ }^{3}$ \\ ${ }^{1}$ Department of Chemistry, Obafemi Awolowo University, Ife, Nigeria \\ ${ }^{2}$ Research Focus Area for Chemical Resource Beneficiation, Laboratory for Analytical Services, North-West University, \\ Potchefstroom, South Africa \\ ${ }^{3}$ Department of Pharmaceutics, Obafemi Awolowo University, Ife, Nigeria \\ Email: taiyelabola@gmail.com, Johan.Jordaan@nwu.ac.za,Daniel.Otto@nwu.ac.za, eoakinmi@oauife.edu.ng, \\ *taiyelabola@oauife.edu.ng
}

How to cite this paper: Aiyelabola, T., Jordaan, J., Otto, D. and Akinkunmi, E. (2020) Synthesis Characterization and Biological Activities of an Enamine Derivative and Its Coordination Compounds. Advances in Biological Chemistry, 10, 172-189. https://doi.org/10.4236/abc.2020.106013

Received: October 16, 2020

Accepted: December 19, 2020

Published: December 22, 2020

Copyright $\odot 2020$ by author(s) and Scientific Research Publishing Inc. This work is licensed under the Creative Commons Attribution International License (CC BY 4.0).

http://creativecommons.org/licenses/by/4.0/

\begin{abstract}
The medicinal uses and applications of metal complexes are of increasing clinical and commercial importance; this is as a result of some level of success achieved so far. In this regard, novel enamine free-base ligands were synthesized by the condensation of terephthalaldehyde and 2-(methylamino)ethanol. This afforded a dinegative $O N N O$ donor enamine, free base, characterized using ${ }^{1} \mathrm{H}$ and ${ }^{13} \mathrm{C} \mathrm{NMR}$, Fourier-transformed infrared and UV-vis spectroscopy. Coordination compounds of the enamine were also synthesized using $\mathrm{Cu}$ (II), $\mathrm{Ni}(\mathrm{II}), \mathrm{Co}(\mathrm{II})$ and VO(IV) ions. These complexes were characterized by electronic, IR spectrophotometry, mass spectrometry, magnetic susceptibility and EDX. The compounds were thereafter evaluated for their antimicrobial and cytotoxic activities. The data obtained were supportive of an octahedral geometry for the $\mathrm{Cu}$ (II) complex, a square-pyramidal geometry for the vanadium complex and a 4-coordinate square-planar geometry for both the cobalt and nickel complexes. The magnetic susceptibility data revealed that the complexes are magnetically dilute and mononuclear with exception of the cobalt complex. The ligands and the complexes did not exhibit significant antimicrobial and cytotoxic assays, indicative of the nontoxicity of the ligand and complexes.
\end{abstract}

\section{Keywords}

Enamine, Nuclear Magnetic Resonance, Antimicrobial Activity, Cytotoxicity, EDX, Therapeutic Coordination Compound, Brine Shrimp Lethality Bioassay 


\section{Introduction}

A fundamental principle in coordination chemistry is the tuning of the properties of metal ions using different ligands [1]-[7]. As a result, syntheses of different compounds with desired properties by ligand tailoring have become a fascinating research field. Of great interest, and in high demand, are new coordination compounds with therapeutic properties [8] [9] [10] [11] [12]. This may be attributed to the success achieved with some inorganic compounds such as cisplatin against cancer, trisenox for acute promyelocytic leukemia and flamazine as an antibacterial in the treatment of burn wounds [13] [14] [15] [16]. From this perspective, there has been a growing interest in the chemistry community to examine the biological activities of compounds such as enamines and their coordination compounds [17]-[29].

Enamines are species that have an amino moiety bound to a doubly bonded carbon atom (Figure 1). This group of compounds and their derivatives represent an important class of compounds with diverse biological activities, which include anti-convulsant, -microbial, -cancer, -inflammatory and -tumor properties [17]-[24]. Enamines have three potential sites of interaction with metal ions viz: the nucleophilic carbon, nitrogen atom and the $\pi$-system of the carbon-carbon double bond. Previous studies have however shown that enamines generally coordinate to metal ions via either the nitrogen atom or the $\pi$-system of the carbon-carbon double bond [17]-[24]. Compounds bearing the enamine moiety may be designed with strategically placed donor atoms such that chelation may be achieved. Hence, enhanced stability of the resultant coordination compound occurs [24]-[29].

It has been shown from previous reports, that coordination of metal ions to biologically active agents may not only tune the metal ion properties, but also the properties of the ligands themselves. Therefore, it may lead to altered activity of such compounds [25]-[42]. There is however, a dearth of information regarding the antimicrobial and cytotoxic activities of thesecompounds and their coordination compounds.

An important consideration for any drug synthesis is the balance between its activity and toxicity [13]. As a result of resistance and toxicity to normal cells, the clinical usage of some anti-cancer and -microbial drugs is being limited [13]. There is therefore, a growing need for obtaining potential anti-microbial and -cancer agents, more importantly, lead compounds with minimal side effects [13].

Consequently, this resulted in the synthesis of a novel enamine derivative, ligand $\mathbf{L}$, obtained by the reaction of terephthalaldehyde and 2-(methylamino)ethanol (Figure 1). This was characterized by ${ }^{1} \mathrm{H}$ and ${ }^{13} \mathrm{C}$ nuclear magnetic resonance, Fourier-transformed infrared (FTIR) and UV-vis spectrometry. Coordination compounds of the enamine were also synthesized using copper(II), nickel(II), cobalt(II) and vanadium(IV) ions. These were characterized using Fourier-transformed infrared and UV-vis spectroscopy, magnetic susceptibility, mass 
<smiles>[R]C([R])=CN([R3])[R3]</smiles>

a

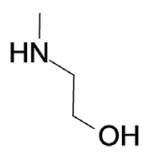<smiles>O=Cc1ccc(C=O)cc1</smiles>

b

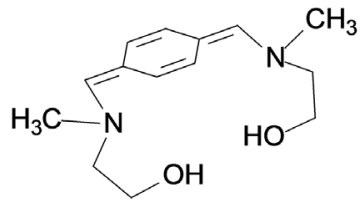

d

Figure 1. (a) Enamine, (b) Terephthalaldehyde, (c) 2-(methylamino)ethanol and (d) Ligand L.

spectrometry and energy-dispersion X-ray spectroscopy (EDX). The antimicrobial activity and brine shrimp lethality bioassay for these compounds were determined. The metal complexes and the ligand are new and the biological activities evaluated are being reported here for the first time.

\section{Materials and Methods}

All starting materials and solvents used were purchased from Aldrich and Fluka and were used without further purification. The melting points were determined on a Gallenhamp melting point apparatus and are uncorrected. The infrared spectra were recorded in the region $4000-400 \mathrm{~cm}^{-1}$ on a Nicolet 410 impact Fourier-Transform infrared spectrophotometer at North West University, Mafikeng Campus. Electronic transitions were measured on a Varian Cary 50 UV-visible spectrophotometer also at the North West University; measurements were made from 200 to $800 \mathrm{~nm}$. Magnetic susceptibility measurements were carried out at room temperature in the Department of Chemistry, Kwara State University, Ilorin, using a Sherwood scientific balance with $\left[\mathrm{HgCo}(\mathrm{SCN})_{4}\right]$ as standard. EDX analyses were obtained using Shimadzu Ray ny EDX 720 at the Department of Chemistry North West University, Mafikeng Campus. The mass spectrum was obtained at the Laboratory for Analytical Services, North West University, Potchefstroom, on a Bruker Ser\# 10390 micrOTOF-Q II mass spectrometer, using atmospheric pressure and chemical ionization APCI. NMR spectra were recordedon a Bruker spectrophotometer topspin2.1PL6 model ultra shield plus at $600 \mathrm{MHz}$ for ${ }^{1} \mathrm{H}$ NMR spectrum and $150 \mathrm{MHz}$ for ${ }^{13} \mathrm{C}$ spectrumin DMSO- $d_{6}$ with TMS as internal standard. Screening of the compounds for antimicrobial activity was done at the Pharmaceutics Laboratory, Obafemi Awolowo University, Ile-Ife. Brine shrimp lethality assay was carried out at the Department of Biochemistry and Molecular Biology, Obafemi Awolowo University, Ile-Ife.

The complexes were synthesized in situ by refluxing the reaction mixture of ethanolic solution of terephthalaldehyde, the secondary amine, 2-(methylamino)ethanol 
and a solution of the corresponding metal ion salt. The compounds were synthesized using adaptation of previous reports [43] [44].

\subsection{Syntheses of Ligand and Coordination Compounds}

\subsubsection{Synthesis of Ligand $\mathrm{L}$}

A solution of 2-(methylamino)ethanol $(1.61 \mathrm{~mL}, 0.02 \mathrm{M})$ in absolute ethanol was added to a stirring solution of terephthalaldehyde $(1.34 \mathrm{~g}, 0.01 \mathrm{M})$ in $30 \mathrm{~mL}$ absolute ethanol. Four drops of glacial acetic acid was added to this and the resultant solution refluxed for $4 \mathrm{~h}$. A yellow precipitate was obtained, which was recrystallized using ethanol-water mixture $(70 / 30, \mathrm{v} / \mathrm{v})$, washed, filtered and dried in a vacuum oven at $60^{\circ} \mathrm{C}$ to givel L. $1.61 \mathrm{~g}(64 \%)$, M.p: $120^{\circ} \mathrm{C}-122^{\circ} \mathrm{C}$. The compound was soluble in chloroform, ethanol and methanol.

${ }^{1} \mathrm{H}$ NMR (600 MHz): DMSO- $d_{6} \delta(\mathrm{ppm}): 10.12(\mathrm{~d}, 2 \mathrm{H}, \mathrm{OH}), 8.06(\mathrm{~m}, 4 \mathrm{H}$, Ar-H), 3.34 (s, 2H, N-CH=), 2.49(t, $\left.4 \mathrm{H}, J=1.8 \mathrm{~Hz}, \mathrm{CH}_{2}\right), 2.02\left(\mathrm{~s}, 4 \mathrm{H}, \mathrm{CH}_{2}\right), 1.89$ $\left(\mathrm{s}, 6 \mathrm{H}, \mathrm{CH}_{3}\right){ }^{13} \mathrm{C}$ NMR $(150 \mathrm{MHz})$ : DMSO- $d_{6} \delta(\mathrm{ppm}): 193.66,133.17$ and 40.04 .

\subsubsection{Cu Complex}

An ethanolic solution of terephthalaldehyde $(1.34 \mathrm{~g}, 0.01 \mathrm{M})$ was heated whilst stirring. A solution of 2-(methylamino)ethanol $(1.61 \mathrm{~mL}, 0.02 \mathrm{M})$ and a solution of copper(II) chloride ( $1.36 \mathrm{~g}, 0.01 \mathrm{M})$ in absolute ethanol, were added dropwise. The reaction solution was then refluxed for $4 \mathrm{~h}$ after the addition of 4 drops of glacial acetic acid. A pale blue precipitate was obtained, which was recrystallized using ethanol-water mixture $(70 / 30, \mathrm{v} / \mathrm{v})$, washed, filtered and dried in a vacuum oven at $60^{\circ} \mathrm{C}$ to give a green precipitate as the Copper(II) complex of L. Yield: 2.17 g (69\%). M.p: $298^{\circ} \mathrm{C}-300^{\circ} \mathrm{C}$ (d), metal composition (\%): anal: 21.04; cal.: 20.71. The complex was sparingly soluble in ethanol, methanol and water. A similar method was used to synthesize the coordination compounds.

\subsubsection{Ni Complex}

An ethanolic solution of terephthalaldehyde $(1.35 \mathrm{~g}, 0.01 \mathrm{M})$ was poured into a round bottom flask and was subsequently heated and stirred. To this was added 2-(methylamino)ethanol (1.66 mL, $0.02 \mathrm{M}$ ) and a solution of nickel(II) chloride $(1.76 \mathrm{~g}, 0.01 \mathrm{M})$ in absolute ethanol, which were added dropwise. Further addition of four drops of glacial acetic acid and catalytic amount of titanium tetrachloride $(0.19 \mathrm{~g}, 0.001 \mathrm{M})$ in $5 \mathrm{~mL}$ of trimethylamine was made. The mixture was then refluxed for 4 hto afford a pale green precipitate, which was recrystallized using water-ethanol mixture $(80 / 20, \mathrm{v} / \mathrm{v})$, washed, filtered and dried in a vacuum oven at $60^{\circ} \mathrm{C}$ to give $\mathrm{Ni}(\mathrm{II})$ complex. Yield: $1.60 \mathrm{~g}$ (52\%), M.p: $290^{\circ} \mathrm{C}$ $292^{\circ} \mathrm{C}$ (d); metal composition (\%): anal.: 20.13; cal.: 19.86, $[\mathrm{M}+1]^{+} .(\mathrm{m} / \mathrm{z}): 310$. The complex was sparingly soluble in ethanol, methanol but soluble in water.

\subsubsection{Co Complex}

An ethanolic solution of terephthalaldehyde $(1.34 \mathrm{~g}, 0.01 \mathrm{M})$ was prepared by heating in absolute ethanol. Subsequently, a solution of 2-(methylamino)ethanol $(1.61 \mathrm{~mL}, 0.02 \mathrm{M})$ and a solution of cobalt(II) chloride $(2.05 \mathrm{~g}, 0.015 \mathrm{M})$ in ab- 
solute ethanol were added. Four drops of glacial acetic acid and catalytic amount of titanium tetrachloride $(0.19 \mathrm{~g}, 0.001 \mathrm{M})$ in $5 \mathrm{~mL}$ of triethylamine were thereafter added. The resultant mixture was refluxed for $4 \mathrm{~h}$. A pink precipitate was obtained, which was recrystallized using ethanol mixture $(80 / 20, \mathrm{v} / \mathrm{v})$, washed and filtered and dried in a vacuum oven at $60^{\circ} \mathrm{C}$ to give the $\mathrm{Co}$ (II) complex. Yield: $1.88 \mathrm{~g}$ (61\%), M.p: $132^{\circ} \mathrm{C}-134^{\circ} \mathrm{C}$ (d), metal composition (\%): anal.: 20.23; cal.: 19.58. The complex was sparingly soluble in ethanol, methanol but soluble in water.

\subsubsection{Vo Complex}

An ethanolic solution of terephthalaldehyde $(1.34 \mathrm{~g}, 0.01 \mathrm{M})$, was prepared and heated. To this solution was added a solution of 2-(methylamino)ethanol (1.61 $\mathrm{mL}, 0.02 \mathrm{M})$ and a solution of vanadyl sulphate $(1.72 \mathrm{~g}, 0.01 \mathrm{M})$ in absolute ethanol. Furthermore catalytic amount of titanium tetrachloride $(0.19 \mathrm{~g}, 0.001$ $\mathrm{M}$ ) in $5 \mathrm{~mL}$ of triethylamine and four drops of glacial acetic acidwas added. The resultant reaction mixture was subsequently refluxed for $4 \mathrm{~h}$. A bluish green precipitate was obtained, which was recrystallized using ethanol-water mixture $(70 / 30 \mathrm{v} / \mathrm{v})$, washed, filtered and dried in a vacuum oven at $60^{\circ} \mathrm{C}$ to give the vanadyl complex. Yield: $1.87 \mathrm{~g}$ (59\%), M.p: $168^{\circ} \mathrm{C}-180^{\circ} \mathrm{C}$, metal composition (\%): anal.: 23.52; cal.: 22.24. The complex was sparingly soluble in ethanol, methanol and water.

\subsection{Antimicrobial Activity}

The organisms used were five Gram-positive and three Gram-negative bacteria and two fungi. These were Staphylococcus aureus (ATCC 29213), Staphylococcus epidermidis (clinical strain), Bacillus subtilis 12 (NCIB 3610), Bacillus subtilis 82 (NCIB 6349), Clostridium sp. (NCIB 532), Klebsiella pneumonia (clinical strain), Pseudomonas aeruginosa (ATCC 27853), Escherichia coli (ATCC 25922), Candida albicans (ATCC 24433) and Candida pseudotropicalis (NCYC 6), respectively. The agents were dissolved in water at room temperature or hot water as appropriate to give a concentration of $40 \mathrm{mg} / \mathrm{mL}$.

The resulting solutions were used to soak sterile Whatman No 2 discs (diameter of $6 \mathrm{~mm}$ ) and allowed to dry in an oven at $50^{\circ} \mathrm{C}$ ). The discs were then utilized to determine antibacterial and antifungal activities as previously described by Aiyelabola et al. [45]. Discs that were impregnated with imipenem and chlorhexidine were used as positive controls for bacteria and fungi, respectively. Zones of inhibition were used as indices of antimicrobial actions.

\subsection{Cytotoxicity Bioassay}

The procedure used was modified from the assay described by Solis et al. [46]. Brine shrimp (Artemia salina) were hatched from shrimp eggs in a conical shaped vessel $(1 \mathrm{~L})$. Subsequently the vessel was filled with sterile, artificial seawater under continuous aeration for $48 \mathrm{~h}$. After hatching, active nauplii free from eggshells were collected from brighter portion of the hatching chamber. 
These were employed for the assay.

Ten nauplii were drawn through a Pasteur pipette and placed in each vial containing $4.5 \mathrm{mg} / \mathrm{L}$ of brine solution. In each experiment, different volumes of the sample chelates were added to $4.5 \mathrm{~mL}$ of brine solution. This produced different concentrations of 20,40,60, 80 and $100 \mu \mathrm{g} / \mathrm{mL}$. Solutions were maintained at room temperature for $24 \mathrm{~h}$ under light. The surviving larvae were counted.

Experiments were conducted along with the control (vehicle treated), of the test substances in a set of three tubes per dose. Estimation of the $\mathrm{LC}_{50}$ values was estimated using probit ${ }^{\oplus}$ analysis on a USEPA computer program.

\section{Results}

\subsection{Ligand}

\subsubsection{NMR}

Evidence for the formation of an enamine was obtained from the ${ }^{1} \mathrm{H}$ NMR data of ligand $\mathrm{L}$ as evidenced by the singlet observed at $\delta 3.34 \mathrm{ppm}$. This is ascribed to enamine protons $(-\mathrm{C}=\mathrm{CH}-\mathrm{N})$, and thus suggestive of the formation of a double bond [47] [48] [49]. This was supported by the disappearance of the signal for the aldehylic proton present in the spectrum of the terephathaldehyde, one of the starting reagents, and the proton of the tertiary amine, which was also a starting reagent.

The spectrum of compound $\mathrm{L}$ further exhibited a triplet with $\delta$ at $8.06 \mathrm{ppm}$, characteristic of aromatic protons [47] [48] [49] [50]. A triplet was observed at $\delta$ $2.49 \mathrm{ppm}$, and was ascribed to the methylene protons $\left(-\mathrm{N}^{-} \mathrm{CH}_{2}-\mathrm{CH}_{2}\right)$ attached to the tertiary amine. The methylene protons attached to the alcohol $\left(-\mathrm{HO}-\mathrm{CH}_{2}-\mathrm{CH}_{2}\right)$, however, resonated as a singlet at $\delta 2.02 \mathrm{ppm}$. A signal at $\delta 1.89 \mathrm{ppm}$ was assigned to the methyl protons attached to the tertiary amine $\left(\mathrm{N}-\mathrm{CH}_{3}\right)$ [47] [48]. Evidence that the hydroxyl substituent was not deprotonated was given by the doublet observed at $\delta 10.12 \mathrm{ppm}$. This multiplicity suggests the non-planarity of this molecule.

The ${ }^{13} \mathrm{C}$ NMR confirmed the formation of an enamine by the observed signal attributable to the allyllic carbon $(\mathrm{C}=\mathrm{C}-\mathrm{N})$ [47] [48], which resonated at $\delta 139.73$ ppm as a singlet. A quadriplet was observed downfield at $\delta 193.66 \mathrm{ppm}$, attributed to the carbon attached to the hydroxyl substituent $\left(\mathrm{CH}_{2}-\mathrm{OH}\right)$ [47] [48]. This however, corroborated the non-planarity of the molecule and probable hydrogen bonding and therefore, of the splitting of this signal to produce the quadruplet [47] [48] [51]. A multiplet observed at $\delta 133.17 \mathrm{ppm}$ was assigned to aromatic carbon. Another multiplet observed at $\delta 40.04 \mathrm{ppm}$ was ascribed to the methylene carbon $\left(\mathrm{CH}_{2}-\mathrm{N}\right)$ attached to the tertiary amine. This observed multiplicity; further confirmed the non-planarity of the molecule [47] [48] [51].

\subsubsection{Fourier-Transformed Infrared Spectrum}

The FTIR spectrum of $\mathrm{L}$ exhibited a weak broad band at $3699 \mathrm{~cm}^{-1}$ assignable to the $(\mathrm{O}-\mathrm{H})$ stretching frequency of an alcohol [47] [48] [52]. Sharp, extended 
bands were observed at $3788 \mathrm{~cm}^{-1}$ and these suggested hydrogen bonding [47] [48] [52]. This was further corroborated by a weak and broad band at $2865 \mathrm{~cm}^{-1}$ and the $v(\mathrm{C}-\mathrm{OH})$ observed at $1010 \mathrm{~cm}^{-1}$ [47] [48] [52].

A sharp band at $1687 \mathrm{~cm}^{-1}$ was attributed to the $v(\mathrm{C}=\mathrm{C})+v(\mathrm{C}-\mathrm{N})$ [47]. Previous studies have suggested that this is indicative of the formation of a carbon-nitrogen bond [52]. A broad weak band at $1587 \mathrm{~cm}^{-1}$ according to Nakamoto 2009 , may be ascribed to the $v(\mathrm{C}=\mathrm{N})+v(\mathrm{C}=\mathrm{C})$, thus validating the formati, on the enamine [52]. Further attesting to this was the absence of $\mathrm{N}-\mathrm{H}$ stretching frequency, present in the starting reagent [47] [48] [52]. This was supported by the presence of the bands at 1497,1384 and $1300 \mathrm{~cm}^{-1}$ ascribable to the following vibrational frequencies $v(\mathrm{C}=\mathrm{N})+\delta(\mathrm{C}-\mathrm{H}), \delta(\mathrm{C}-\mathrm{H})+v(\mathrm{C}-\mathrm{N})$ and $\delta(\mathrm{C}-\mathrm{H})+v(\mathrm{C}-\mathrm{N})$, respectively [47] [48] [52]. A medium band observed at 1193 $\mathrm{cm}^{-1}$, typical of the $v(\mathrm{C}-\mathrm{N})$, further confirmed the formation of the carbon-nitrogen bond and therefore supported the formation of an enamine. A band observed at $1428 \mathrm{~cm}^{-1}$ was assigned to the $\delta\left(\mathrm{CH}_{3}\right)$ of the methyl group attached to the tertiary amine [47] [48] [52].

\subsubsection{Electronic Spectrum}

The spectrum of ligand $\mathrm{L}$ exhibited a band at 202, 220 and $345 \mathrm{~nm}$ these are attributed as $\mathrm{n} \rightarrow \sigma^{*}, \mathrm{n} \rightarrow \pi^{*}$ and $\pi^{*} \rightarrow \pi^{*}$ transitions for the major chromophores in $\mathrm{L}$, hydroxyl, tertiary amine and $\mathrm{sp}^{2}$ hybridized carbon. These results confirmed the expectation that the ligand was produced successfully [47] [48] [53].

\subsection{Complexes of Ligand $L$}

\subsubsection{Copper(II) Complex}

The infrared spectrum of the copper(II) complex provided evidence for the formation of the ligand and coordination of the copper(II) ion with the ligand. This was evidenced by the shift in some of the observed frequency bands in comparison with that of the ligand. The spectrum showed two bands at 3462 and 3367 $\mathrm{cm}^{-1}$ which were assignable to the $(\mathrm{O}-\mathrm{H})$ stretching frequency [47] [48] [52] [54] [55]. Thus, indicative of a bathochromic shift of about $237 \mathrm{~cm}^{-1}$ in comparison with that obtained for the ligand. Supporting the $v(\mathrm{O}-\mathrm{H})$ frequency was the band at $1035 \mathrm{~cm}^{-1}$ and ascribed to the $v(\mathrm{C}-\mathrm{OH})$ indicative of a hypsochromic shift in comparison with the ligand [47] [48] [52].

Both batochromic and hypsochromic shifts suggest coordination of the oxygen atom of the hydroxyl substituent to the central metal ion [47] [48] [52]. Further supporting evidence was the $v(\mathrm{Cu}-\mathrm{O})$ observed at 688 and $628 \mathrm{~cm}^{-1}$ [52] [56] [57]. Additionally another band observed in the spectrum of the complex at $1597 \mathrm{~cm}^{-1}$ which was attributable to $v(\mathrm{C}=\mathrm{N})+v(\mathrm{C}=\mathrm{C})$ stretching frequency further alluded to the formation of an enamine [47]. Supporting this was the $v(\mathrm{C}=\mathrm{N})+\delta(\mathrm{C}-\mathrm{H})$ observed at $1440 \mathrm{~cm}^{-1}$. Coordination of the metal ion with the nitrogen atom of the enamine was suggested by the $v(\mathrm{Cu}-\mathrm{N})$ observed at 568 $\mathrm{cm}^{-1}$ [52] [56] [58] [59] [60].

The electronic spectrum of the $\mathrm{Cu}(\mathrm{II})$ complex exhibited two bands in the ul- 
traviolet region at 234 and $309 \mathrm{~nm}$. These bands correspond to shifts in the $\mathrm{n} \rightarrow$ $\sigma^{\star}$ and $n \rightarrow \pi^{\star}$ transitions in relation with the ligand and thus, is indicative of the coordination of the ligand with the copper(II) ion.

Conversely, the visible region elucidated a band at $634 \mathrm{~nm}$ and a shoulder at $506 \mathrm{~nm}$ typical for a tetragonally distorted octahedral configuration and may be assigned to ${ }^{2} \mathrm{~B}_{1 \mathrm{~g}} \rightarrow{ }^{2} \mathrm{~A}_{1 \mathrm{~g}}$ and ${ }^{2} \mathrm{~B}_{1 \mathrm{~g}} \rightarrow{ }^{2} \mathrm{E}_{\mathrm{g}}$ transition. The magnetic moment of 2.54 $\mathrm{BM}$, further corroborates an octahedral geometry [5] [6] [61] [62].

\subsubsection{Nickel(II) Complex}

The FTIR spectrum for the nickel(II) complex of L elucidated a band at 3446 $\mathrm{cm}^{-1}$ attributable $v(\mathrm{O}-\mathrm{H})$ and is indicative of a bathochromic shift in relation with that obtained for the free base [47] [48] [52] [54] [55]. Supporting this was the band at $1035 \mathrm{~cm}^{-1}$ ascribed to the $v(\mathrm{C}-\mathrm{OH})$ (Table 1) [47] [48]. Evidence for the coordination of the metal ion with the oxygen atom of the hydroxyl moiety was suggested by the $v(\mathrm{Ni}-\mathrm{O})$ observed at $624 \mathrm{~cm}^{-1}$. Two sharp bands at 1676 $\mathrm{cm}^{-1}$ ascribed to the $v(\mathrm{C}=\mathrm{C})+v(\mathrm{C}-\mathrm{N})$ and $1583 \mathrm{~cm}^{-1} v(\mathrm{C}=\mathrm{N})+v(\mathrm{C}=\mathrm{C})$ corroborated the formation of an enamine. A band obtained at $1172 \mathrm{~cm}^{-1}$ was attributed to the $v(\mathrm{C}-\mathrm{N})$, thus suggestive of the formation of carbon-nitrogen bond. Further evidence for the support of the coordination of the metal ion was given by the $v(\mathrm{Ni}-\mathrm{N})$ at $545 \mathrm{~cm}^{-1}$ [52] [56] [59].

The UV spectrum for this complex displayed a band at $324 \mathrm{~nm}$, indicative of a shift in the $n \rightarrow \pi^{*}$ compared with the ligand and thus serves as evidence of the coordination of the ligand with the metal ion. The spectrum for the Ni(II) complex showed $d$ - $d$ bands at 525 and $714 \mathrm{~nm}$, which were assigned to spin-allowed transitions of ${ }^{3} \mathrm{~A}_{2 g}(\mathrm{~F}) \rightarrow{ }^{5} \mathrm{~T}_{1 \mathrm{~g}}(\mathrm{~F})$ and ${ }^{3} \mathrm{~A}_{2 \mathrm{~g}}(\mathrm{~F}) \rightarrow{ }^{5} \mathrm{~T}_{1 \mathrm{~g}}(\mathrm{P})$ suggestive of a four-coordinate square-planar geometry [63]. The magnetic moment of $0.00 \mathrm{BM}$ validated a square planar geometry for the complex [33].

\subsubsection{Cobalt(II) Complex}

Although the infrared spectrum of the cobalt(II) complex did not exhibit a distinctive $v(\mathrm{O}-\mathrm{H})$, weak, sharp extended bands were observed at about $3462 \mathrm{~cm}^{-1}$ (Table 1). These bands were suggestive of hydrogen bonding. Corroborating the presence of hydrogen bonding was the band observed at $1027 \mathrm{~cm}^{-1}$ assignable to $v(\mathrm{C}-\mathrm{OH})$. Similar to what obtained for compounds 1 and 2 , the shifts in these vibrational frequencies in relation to the ligand suggested the involvement of the oxygen atom of the hydroxyl moiety of the ligand in coordination with the metal ion. Corroborating this was the band at $623 \mathrm{~cm}^{-1}$ and was ascribed to the (Co-O) stretching frequency.

Confirming the formation of the enamine was the absence of the carbonyl stretching frequency of terephthalaldehyde in conjunction with the band observed at $1575 \mathrm{~cm}^{-1}$ and ascribed to the $(C=N)+(C=C)$ stretching vibrational frequencies. The band observed at $546 \mathrm{~cm}^{-1}$, which was absent in the ligand, was assigned to the $v(\mathrm{Cu}-\mathrm{N})$ may serve as further evidence for coordination of the nitrogen atom of the ligand to the metal ion. 
Table 1. Relevant infrared spectra bands for the ligand and complexes $\left(\mathrm{cm}^{-1}\right)$.

\begin{tabular}{|c|c|c|c|c|c|c|c|c|c|}
\hline Compound & $v(\mathrm{O}-\mathrm{H})$ & $\begin{array}{c}v(\mathrm{C}=\mathrm{C}) \\
+v(\mathrm{C}-\mathrm{N})\end{array}$ & $\begin{array}{c}v(\mathrm{C}=\mathrm{N}) \\
+v(\mathrm{C}=\mathrm{C})\end{array}$ & $\begin{array}{c}v(\mathrm{C}=\mathrm{N}) \\
+\delta(\mathrm{C}-\mathrm{H})\end{array}$ & $\begin{array}{c}\delta(\mathrm{C}-\mathrm{H}) \\
+v(\mathrm{C}=\mathrm{N}\end{array}$ & $v(\mathrm{C}-\mathrm{N})$ & $v(\mathrm{C}-\mathrm{OH})$ & $v(\mathrm{M}-\mathrm{N})$ & $v(\mathrm{M}-\mathrm{O})$ \\
\hline Ligand & 3699 & 1687 & 1587 & 1440 & 1384,1300 & 1193 & 1010 & - & - \\
\hline $\mathrm{Cu}(\mathrm{II})$ & 3462 & - & 1597 & - & - & - & 1035 & 688,628 & 568 \\
\hline $\mathrm{Ni}(\mathrm{II})$ & 3367 & 1676 & 1583 & - & 1334 & 1172 & 1040 & 624 & 545 \\
\hline $\mathrm{Co}(\mathrm{II})$ & 3446 & - & 1575 & - & - & - & 1027 & 623 & 546 \\
\hline VO(IV) & 3462 & - & - & 1432 & - & - & - & 664 & 525 \\
\hline
\end{tabular}

The electronic spectrum of compound exhibited two bands in the UV region at 224 and 325 assignable to $\pi \rightarrow \pi^{*}$ and $n \rightarrow \pi^{*}$ transitions of the ligand. It also exhibited two bands in the visible region at $765 \mathrm{~nm}$ and $536 \mathrm{~nm}$ corresponding to ${ }^{4} \mathrm{~A}_{2}(\mathrm{~F}) \rightarrow{ }^{4} \mathrm{~T}_{2}(\mathrm{~F})$ and ${ }^{4} \mathrm{~A}_{2}(\mathrm{~F}) \rightarrow{ }^{4} \mathrm{~T}_{1}(\mathrm{P})$, respectively [47] [48].

The effective magnetic moment for the complex was $1.96 \mathrm{BM}$. This observed magnetic moment was much lower than that expected for high spin cobalt(II) complex with $d$ configuration. This may be interpreted according to previous reports to be attributable to four-coordinate, square planar geometry for cobalt(II) with antiferromagnetism. This feature was studied previously by other workers and they suggested that the subnormality in the magnetic moments may be ascribed to antiferromagnetism which is due to the interaction between electron spins on neighbouring metal ions [64] [65] [66] [67]. It is generally accepted that the mechanism of the exchange interactions involves the mutual pairing of electron spins via orbital overlap. Antiferromagnetic exchange may be metal-metal interaction or super-exchange. Metal-metal interactions involve direct overlap of orbitals containing the unpaired electrons, which influences the magnetic behaviour whereas super exchange involves the interaction of electrons with opposite spins on the two interacting ions via an intermediate diamagnetic anion(s), which results in effective pairing leading to a minimum number of unpaired spins in the ground state of the system. Both mechanisms seem to be active, thereby leading to the observed magnetic moment [64] [65] [66].

\subsubsection{Vanadyl(IV) Complex}

The FTIR spectrum of the complex elucidated a band at $3462 \mathrm{~cm}^{-1}$ which was assignable to the $v(\mathrm{O}-\mathrm{H})[52]$. This indicated a bathochromic shift as coordination of the oxygen atom of the hydroxyl substituent to the central metal ion. The $v(\mathrm{~V}-\mathrm{O}) 664 \mathrm{~cm}^{-1}$ further supports this. Supporting this was the $v(\mathrm{C}=\mathrm{N})+\delta(\mathrm{C}-\mathrm{H})$ observed at $1432 \mathrm{~cm}^{-1}$ (Table 1). The spectrum of the complex also exhibited a new medium intensity band in the region $525 \mathrm{~cm}^{-1}$ which was ascribed to the $(\mathrm{V}-\mathrm{N})$, thus suggestive of the coordination of the metal ion with the nitrogen atom of the enamine. Corroborating this was the absence of the carbonyl and amine stretching frequencies. The spectrum exhibited a signal at $980 \mathrm{~cm}^{-1}$ attributable to the $v(\mathrm{~V}=\mathrm{O})$ [67]. 
The electronic spectrum of compound 4 revealed two bands in the 236 and $379 \mathrm{~nm}$ UV region that were ascribed to $\mathrm{n} \rightarrow \pi^{*}$ and $\pi^{*} \rightarrow \pi^{*}$ transitions, Table 2. The visible region of the spectrum exhibited two bands at 450 , and $847 \mathrm{~nm}$ typical for a square pyramidal geometry and assigned to ${ }^{2} \mathrm{~B}_{2} \rightarrow{ }^{2} \mathrm{E}_{1}$ and ${ }^{2} \mathrm{~B}_{2} \rightarrow{ }^{2} \mathrm{~A}_{1}$ transitions respectively. The magnetic moment obtained for the complex further supports the square pyramidal geometry.

\subsection{Antimicrobial Properties}

The ligand $\mathrm{L}$ and the synthesized complexes were evaluated for their antimicrobial activity against five Gram-positive bacteria, three Gram-negative bacteria and two fungi. The results obtained are presented in Table 3 . The result indicated that $\mathbf{L}$ was inactive against all the tested organisms. The only compound that exhibited any form of antimicrobial activity was vanadyl(IV) complex.

Table 2. Electronic spectra bands (nm) for the ligand and complexes.

\begin{tabular}{cccccc}
\hline Compound & 1 & 2 Bands & $3(\mathrm{~nm})$ & $\mathrm{d}-\mathrm{d}$ & $\mu_{\text {eff }} \mathrm{BM}$ \\
\hline Ligand & 202 & 220 & 345 & - & \\
$\mathrm{Cu}(\mathrm{II})$ & 234 & 309 & 499,614 & 2.54 \\
$\mathrm{Ni}(\mathrm{II})$ & & 324 & 525,880 & 0.00 \\
$\mathrm{Co}(\mathrm{II})$ & 224 & 325 & 765,536 & 1.96 \\
$\mathrm{VO}(\mathrm{IV})$ & 236 & 376 & 450,628 and 847 & 1.75 \\
\hline
\end{tabular}

Table 3. Zone of antimicrobial inhibition $(\mathrm{mm})$ for the ligand and complexes.

\begin{tabular}{ccccccc}
\hline Microbes & $\mathrm{L}$ & $\mathrm{Cu}(\mathrm{II})$ & $\mathrm{Ni}(\mathrm{II})$ & $\mathrm{Co}(\mathrm{II})$ & $\mathrm{VO}(\mathrm{IV})$ & $\mathrm{C}$ \\
\hline S. aureus & - & - & - & - & - & 44 \\
S. epidermidis & - & - & - & - & - & 34 \\
B. subtilis 12 & - & - & - & - & - & 34 \\
B. subtilis 82 & - & - & - & - & - & 29 \\
Clostridium & - & - & - & - & - & 34 \\
K. pneumonia & - & - & - & - & - & 34 \\
P. aeruginosa & - & - & - & - & - & 39 \\
E. coli & - & - & - & - & - & 33 \\
C. albicans & - & - & - & - & - & 36 \\
C. pseudotropicalis. & - & - & - & - & 9 & 36 \\
\hline
\end{tabular}

Where $\mathrm{C}=$ imipenem and chlorhexidine for bacteria and fungi respectively. 


\subsection{Cytotoxicity}

Chemotherapy with cytotoxic drugs is the main treatment modality for certain types of cancer. Cytotoxicity is the quality of an agent to being toxic to cells. The brine shrimp lethality assay serves as a preliminary assay for the cytotoxicity for probable potent compounds [68] [69] [70]. Brine shrimp lethality assays of the synthesized compounds, metal ions and the ligand were conducted.

The result obtained, indicated that the ligand $\mathbf{L}\left(\mathrm{LC}_{50} 153.139 \mu \mathrm{g} / \mathrm{mL}\right)$ was the least active of the compounds. The order of activity for the synthesized compounds is as follows cobalt(II) complex $>$ nickel(II) complex > copper(II) complex > vanadyl(IV) with $\mathrm{LC}_{50}$ values of $111.486,122.107,132.947,133.019 \mu \mathrm{g} / \mathrm{mL}$, respectively.

The standard control substance $\mathrm{K}_{2} \mathrm{Cr}_{2} \mathrm{O}_{7}\left(\mathrm{LC}_{50} 5.56 \mu \mathrm{g} / \mathrm{mL}\right)$, however, exhibited significantly higher cytotoxic activity $(\mathrm{P}<0.05)$ compared with that of the ligands and synthesized compounds. The metal salts exhibited superior activity relative to synthesized compounds. The metal salt cytotoxicity, viz: cobalt(II) chloride, vanadyl suphate, nickel(II) and copper(II) chloride, was ranked in the order of $\mathrm{Co}>\mathrm{VO}>\mathrm{Ni}>\mathrm{Cu},\left(\mathrm{LC}_{50} 30.512,39.466,63.533,91.208 \mu \mathrm{g} / \mathrm{mL}\right)$.

\section{Discussion}

In the preparation of the ligand, $\mathrm{Cu}(\mathrm{II})$ and $\mathrm{Co}(\mathrm{II})$ complexes direct combination of the reactants in absolute ethanol with catalytic amount of glacial acetic acid and refluxing gave products which were then isolated and recrystallized. However, in the case of the Co(II) complexa yield of $33 \%$ was obtained. Synthesesof $\mathrm{Ni}(\mathrm{II})$ and $\mathrm{VO}(\mathrm{IV})$ complexes via this method afforded a gelatinous precipitate. However, on further additionof catalytic amount of titanium tetrachloride, according to White and William, 1967, products were obtained which were recrystallized and dried. It is suggested therefore, that to obtain compounds $\mathrm{Ni}(\mathrm{II})$ andVO(IV) complexes in high yields, a drying agent was required. We do not have any reason for this observed variation.

Based on the results obtained, for the structural analyses of the compounds, it was therefore suggested that the reaction of terephthalaldehyde and the secondary amine; 2-(methylamino)ethanol afforded an enamine. This acted as a teradentate ligand with the use of the enamine nitrogen and the oxygen atom of the hydroxyl moiety, $N, N, O, O$ indicating that both the nucleophilic carbon and the $\pi$-system of the carbon-carbon double bond does not participate in coordination, this is in agreement with previous reports [17]-[24]. On coordination with the cobalt ion, an octahedral complex was obtained. The result obtained for the magnetic moment, the $v(\mathrm{O}-\mathrm{H})$ and $v(\mathrm{Cu}-\mathrm{O})$ suggest the coordination by two molecules of ethanol in addition to the enamine free base, affording a complex of composition $\left[\mathrm{Cu}(\mathrm{L})(\mathrm{et})_{2}\right]$, indicative of an octahedral geometry (Figure 2) [5] [6] [60] [61] [62]. For the $\mathrm{Ni}(\mathrm{II})$ and $\mathrm{Co}(\mathrm{II})$ complexes however square planar complex were obtained (Figure 2). On the other hand, in the case of the vanadium complex a tetragonal-pyramidal complex was suggested (Figure 2). Further 


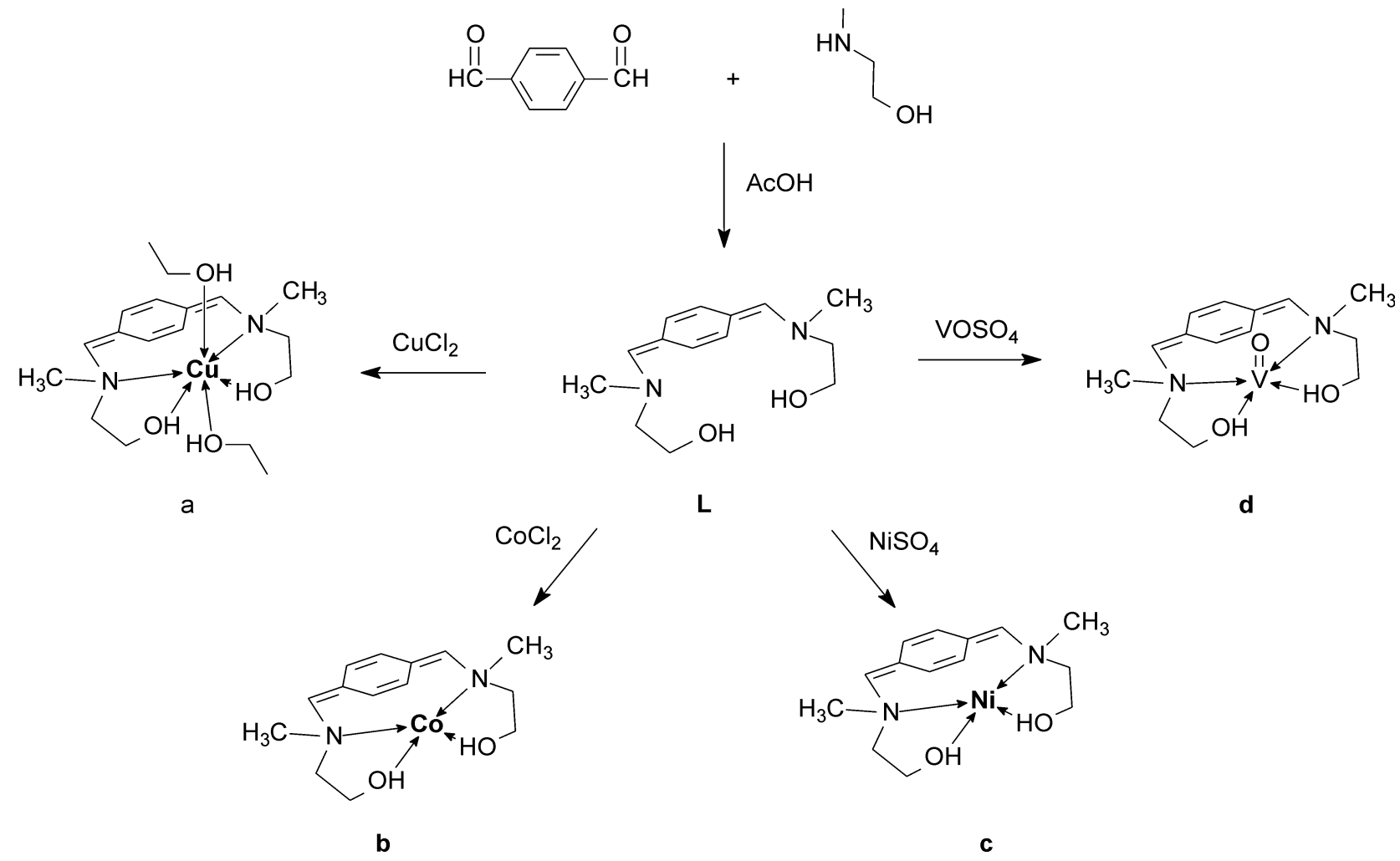

Figure 2. Schematic diagram for the syntheses of ligand L (a) $\mathrm{Cu}$ (II) (b) $\mathrm{Co}$ (II) (c) $\mathrm{Ni}$ (II) (d) VO(IV) complex.

evidence for the proposed geometry for compound 2 was obtained via APCI-MS where the relevant molecular peak at $[M+1]^{+}(\mathrm{m} / \mathrm{z}): 310$ was observed. This finding was supported by the results obtained from the EDX analysis. For all the complexes the percentage metal composition obtained using EDX was in good agreement with that of the proposed structures of the complexes.

Results obtained from the antimicrobial studies for the ligand and complexes, indicated activity for VO(IV) complex only. Previous reports indicated that chelation may increase the lipophilicity of the chelates, resulting in possible enhancement of penetration of the complexes through the lipid membrane of the microbes. Subsequently, the complexes interfere with the normal activities of the microbe, however in this case it was not so [71]-[77]. Chelation did not enhance the antimicrobial activity of the complexes in comparison with the ligand. The clear exception was that of the VO(IV) complex. The reason for the inactivity of the compounds is not readily evident. However, the results obtained, therefore reiterates the fact that increased lipophilicity due to chelation, is effectively a factor that enhances the inherent potential antimicrobial properties of a particular compound. As such it demonstrated the fact that both the former and latter factors are mutually exclusive [74]-[80].

The results obtained from the brine shrimp lethality bioassay of the ligand in comparison with what obtained for the synthesized complexes indicated that coordination enhanced the cytotoxic activity of the complexes relative to the ligand. This is in agreement with previous reports. The results obtained further 
suggest the non-toxic nature of the ligand and hence that of the complexes as well [79] [80].

\section{Conclusion}

The results obtained from this study indicated the formation of an enamine from the reaction of terephthalaldehyde and 2-(methylamino)ethanol. This however coordinated with metal ions via the enamine nitrogen and the oxygen atom of the hydroxyl moiety, $N, N, O, O$ in a tetradentate fashion. The results obtained demonstrated that increased lipophilicity due to chelation is effectively a factor that enhances the inherent potential antimicrobial properties of a compound. On the other chelation increased the cytotoxic activity of the complexes relative to the ligand.

\section{Acknowledgements}

The Laboratory for Analytical Services, Research Focus Area for Chemical Resource Beneficiation, Potchefstroom, South Africa is acknowledged for provision of MS and NMR facilities.

\section{Author's Contributions}

All the authors contributed to the conceptualization and critical revisions of the work and T.O. compiled the original draft.

\section{Conflicts of Interest}

The authors declare no conflict of interest.

\section{References}

[1] Lawrence, G.A. (2009) Introduction to Coordination Chemistry. 1st Edition, John Wiley \& Sons, University of Newcastle, New South Wales, 1-304. https://doi.org/10.1002/9780470687123

[2] Sears, R.B., Joyce, L.E. and Turro, C. (2010) Electronic Tuning of Ruthenium Complexes by 8-Quinolate Ligands. Photochemistry and Photobiology, 86, 1230-1236. https://doi.org/10.1111/j.1751-1097.2010.00814.x

[3] Wilkins, R.G. (1991) The Study of Kinetics and Mechanism of Reactions of Transition Metal Complexes. 2nd Edition, VCH Verlag, Weinheim, 133. https://doi.org/10.1002/3527600825

[4] Tuncer, S., Koca, A., Gül, A. and Avcrata, U. (2012) Synthesis, Characterization, Electrochemistry and Spectroelectrochemistry of Novel Soluble Porphyrazines Bearing Unsaturated Functional Groups. Dyes and Pigments, 92, 610-618. https://doi.org/10.1016/j.dyepig.2011.05.023

[5] Greenwood, N.N. and Earnshaw, A. (1997) Chemistry of the Elements. 2nd Edition, Butterworth-Heinemann, Hong Kong, 1060-1090, 1290-1326.

[6] Cotton, F.A., Wilkinson, G. and Murillo, C.A. (1999) Advanced Inorganic Chemistry. 6th Edition, Wiley Interscience, New York, 420.

[7] Pessoaa, J.C., Etcheverry, S. and Gambinoc, D. (2014) Vanadium Compounds in Medicine Coordination. Coordination Chemistry Reviews, 301-302, 24-48. 
https://doi.org/10.1016/j.ccr.2014.12.002

[8] Glans, L., Ehnbom, A., de Kock, C. Martínez, A., Estrada, J., Smith, P.J., et al. (2012) Ruthenium (II) Arene Complexes with Chelating Chloroquine Analogue Ligands: Synthesis, Characterization and in Vitro Antimalarial Activity. Dalton Transactions, 41, 2764-2773. https://doi.org/10.1039/c2dt12083f

[9] Vela, L., Contel, M., Palomera, L., Azaceta, G. and Marzo, I. (2011) Iminophosphorane-Organogold(III) Complexes Induce Cell Death through Mitochondrial ROS Production. Journal of Inorganic Biochemistry, 105, 1306-1313. https://doi.org/10.1016/j.jinorgbio.2011.06.004

[10] Allardyce, C.S. and Dyson, P.J. (2016) Metal-Based Drugs That Break the Rules Dalton Transactions, 45, 3201-3209. https://doi.org/10.1039/C5DT03919C

[11] van Rijt, S.H. and Sadler, P.J. (2009) Current Applications and Future Potential for Bioinorganic Chemistry in the Development of Anticancer Drugs. Drug Discovery Today, 14, 1089-1097. https://doi.org/10.1016/j.drudis.2009.09.003

[12] Farrer, N.J. and Sadler, P.J. (2011) Bioinorganic Medicinal Chemistry. 3rd Edition, John Wiley \& Sons, New York.

[13] Ferell, N.P. (2003) Metal Complexes as Drugs and Chemotherapeutic Agents. In: McCleverty, J.A. and Meyer, T.J., Eds., Comprehensive Coordination Chemistry II, Vol. 9, Elsevier, Amsterdam, 809-847.

https://doi.org/10.1016/B0-08-043748-6/09021-6

[14] Kostovo, I. (2006) Platinum Complexes as Anticancer Agents. Recent Patents on Anti-Cancer Drug Discovery, 1, 1-22. https://doi.org/10.2174/157489206775246458

[15] Zhang, C.X. and Lippard, S.J. (2003) New Metal Complexes as Potential Therapeutics. Current Opinion in Chemical Biology, 7, 481-489.

https://doi.org/10.1016/S1367-5931(03)00081-4

[16] Keppler, B. (1993) Metal Complexes in Cancer Chemotherapy. VCH-Verlag, Weinheim, New York, 1-42,

[17] Mukherjee, S., Yang, J.W., Hoffman, F. and List, B. (2007) Asymmetric Enamine Catalysis. Chemical Reviews, 107, 5471-5569. https://doi.org/10.1021/cr0684016

[18] Kolomoets, O., Voskoboynik, O., Antypenko, O., Berest, G., Nosulenko, I., et al. (2017) Design, Synthesis and Anti-Inflammatory Activity of Derivatives 10-R-3Aryl-6,7-dihydro-2H-[1,2,4] triazino[2,3-c]quinazolin-2-ones of Spiro-Fused Cyclic Frameworks. Acta Chimica Slovenica, 64, 902-910. http://dx.doi.org/10.17344/acsi.2017.3575

[19] Molvi, K.I., Mansuri, M., Sudarsanam, V., Patel, M.M., Andrabi, S.M. and Haque, N. (2008) Synthesis, Anti-Inflammatory, Analgesic and Antioxidant Activities of Some Tetrasubstitutedthiophenes. Journal of Enzyme Inhibition and Medicinal Chemistry, 23, 829-838. https://doi.org/10.1080/14756360701626082

[20] Teh, C.H., Nazni, W.A., Nurulhusna, A.H., Norazah, A. and Lee, H.L. (2017) Determination of Antibacterial Activity and Minimum Inhibitory Concentration of Larval Extract of Fly via Resazurin-Based Turbidometric Assay. BMC Microbiology, 17, Article No. 36. https://doi.org/10.1186/s12866-017-0936-3

[21] Baldwin, A.G., Bevan, J., Brough, D., Ledder, R. and Freeman, S. (2018) Synthesis and Antibacterial Activities of Enamine Derivatives of Dehydroacetic Acid. Medicinal Chemistry Research, 27, 884-889.

https://doi.org/10.1007/s00044-017-2110-8

[22] Khokhar, A.R., Doran, S.L., Brown, D.B. and Hacker, M.P. (1987) Synthesis and Antitumor Activity of Organometallic cis-Dichloro(Enamine)(Amine) Platinum(II) 
Complexes. Inorganica Chimica Acta, 135, 81-83.

https://doi.org/10.1016/S0020-1693(00)83268-5

[23] Stefańska, B., Dzieduszycka, M., Bontemps-Gracz, M., Borowski, E. and Martelli, S. (1988) Synthesis and Antileukemic Activity of N-Enamine Derivatives of Daunorubicin, 5-Iminodaunorubicin, and Doxorubicin. The Journal of Antibiotics, 41, 193-198.

[24] Chen, K.H., Lin, T.H., Hsu, T.E., Chen, G.H., Leu, W.J., Guh, J.H., Lin, C.H. and Huang, J. (2018) Ruthenium (II) Complexes Containing Dehydroacetic Acid and Its Imine Derivative Ligands. Synthesis, Characterization and Cancer Cell Growth Anti-Proliferation Activity $\left(\mathrm{GI}_{50}\right.$ ) Study. Journal of Organometallic Chemistry, 871, 150-158. https://doi.org/10.1016/j.jorganchem.2018.07.014

[25] Belmar, J., Pérezb, F.R., Alderetea, J. and Zúñig, C. (2005) Synthesis and Tautomeric Studies of Enamines from 1-(n-Hexyl)-3-methyl-2-pyrazolin-5-one. Journal of the Brazilian Chemical Society, 16, 179-189. https://doi.org/10.1590/S0103-50532005000200009

[26] Shi, Y.C., Yang, H.M., Shen, W.B., Yan, C.G. and Hu, X.Y. (2004) Syntheses and Crystal Structures of Ferrocene-Containing Enaminones and Their Copper Complexes. Polyhedron, 23, 15-21. https://doi.org/10.1016/j.poly.2003.08.017

[27] Shi, Y.C., Yang, H.M., Song, H.B. and Liu, Y.H. (2004) Syntheses and Crystal Structures of Ferrocene-Containing Enaminones and Their Copper Complexes. Polyhedron, 23, 1541-1546. https://doi.org/10.1016/j.poly.2004.04.002

[28] Brbot-Saranovi, A., Pavlovi, G., Vrdoljak, V. and Cindri, M. (2001) Synthesis and Structure of Two Isomeric Enaminones. Croatica Chemica Acta, 74, 441-454.

[29] Brbot-Šaranović, A., Pavlović, G. and Cindrić, M. (2000) Synthesis and Structure of New Enaminones. Structural Chemistry, 11, 65-76.

https://doi.org/10.1023/A:1009224507725

[30] Abebe, A. and Hailemariam, T. (2016) Synthesis and Assessment of Antibacterial Activities of Ruthenium(III) Mixed Ligand Complexes Containing 1, 10-Phenanthroline and Guanide. Bioinorganic Chemistry and Applications, 2016, Article ID: 3607924. https://doi.org/10.1155/2016/3607924

[31] Sakurai, H., Yoshikawa, Y., Kawabe, K. and Yasui, H. (2002) Antidiabetic Vanadium(IV) and Zinc(II) Complexes. Coordination Chemistry Reviews, 226, 187-198. https://doi.org/10.1016/S0010-8545(01)00447-7

[32] Chang, E.L., Simmers, C. and Knight, A. (2010) Cobalt Complexes as Antiviral and Antibacterial Agents. Pharmaceuticals, 3, 1711-1728.

https://doi.org/10.3390/ph3061711

[33] Sadlers, P., Muncia, C. and Shipman, M.A. (2007) Biological Inorganic Chemistry: Structure and Reactivity. 3rd Edition, University Science Books, London, 115-136.

[34] Emami, S. and Dadashpour, S. (2015) Current Developments of Coumarin-Based Anti-Cancer Agents in Medicinal Chemistry. European Journal of Medicinal Chemistry, 102, 611-630. https://doi.org/10.1016/j.ejmech.2015.08.033

[35] Georgieva, I., Mihaylov, T. and Trendafilova, N. (2014) Lanthanide and Transition Metal Complexes of Bioactive Coumarins: Molecular Modeling and Spectroscopic Studies. Journal of Inorganic Biochemistry, 135, 100-112. https://doi.org/10.1016/j.jinorgbio.2014.03.003

[36] Butler, I.S., Gilson, D.F.R., Jean-Claude, B.J. and Mostafa, S.I. (2014) Synthesis of New 4-Methylesculetin Complexes as Anti-Neoplastic Agents and X-Ray Structure of Dimeric Bis-Bipyridyl-Bis-4-Methylesculetinato Zinc(II). Inorganica Chimica Acta, 423, 132-143. https://doi.org/10.1016/j.ica.2014.05.048

[37] Ilić, D.R., Jevtić, V.V., Radić, G.P., Arsikin, K., Ristić, B., Harhaji-Trajković, L., et al. 
(2014) Synthesis, Characterization and Cytotoxicity of a New Palladium(II) Complex with a Coumarine-Derived Ligand. European Journal of Medicinal Chemistry, 74, 502-508. https://doi.org/10.1016/j.ejmech.2013.12.051

[38] Thati, B., Noble, A., Creaven, B.S., Walsh, M., Kavanagh, K. and Egan, D.A. (2007) Apoptotic Cell Death: A Possible Key Event in Mediating the in Vitro Anti-Proliferative Effect of a Novel Copper(II) Complex, [Cu(4-Mecdoa)(phen)2] (phen=phenanthroline, 4-Mecdoa=4-methylcoumarin-6,7-dioxactetate), in Human Malignant Cancer Cells. European Journal of Pharmacology, 569, 16-28.

https://doi.org/10.1016/j.ejphar.2007.04.064

[39] Kostova, I., Momekov, G. and Stancheva, P. (2007) New Samarium(III), Gadolinium(III), and Dysprosium(III) Complexes of Coumarin-3-Carboxylic Acid as antiproliferative Agents. Metal-Based Drugs, 2007, Article ID: 15925.

[40] Kostova, I., Momekov, G., Tzanova, T. and Karaivanova, M. (2006) Synthesis, Characterization, and Cytotoxic Activity of New Lanthanum(III) Complexes of Bis-Coumarins. Bioinorganic Chemistry and Applications, 2006, Article ID: 025651. https://doi.org/10.1155/BCA/2006/25651

[41] Aiyelabola, T.O., Ojo, I.A., Adebajo, C.A., Ogunlusi, G.O., Oyetunji, O. and Akinkunmi, E.O. (2012) Synthesis Characterization and Antimicrobial Activities of Some Metal(II) Amino Acid's Complexes. Advances in Biological Chemistry, 2, 268-273. http://dx.doi.org/10.4236/abc.2012.23034

[42] Olaniyi, A. (2005) Essential Medicinal Chemistry. 2nd Edition, Ibadan University Press, Ibadan, 29-42.

[43] Sriram, M., Zhu, Y., Camp, A.W., Day, C.S. and Jones, A.C. (2014) Structure and Dynamic Behavior of Phosphine Gold(I)-Coordinated Enamines: Characterization of a-Metalated Iminiumions. Organometallics, 33, 4157-4164. https://doi.org/10.1021/om500670z

[44] White, W.A. and William, H.W.A. (1967) A Versatile New Enamine Synthesis. The Journal of Organic Chemistry, 32, 213-214. https://doi.org/10.1021/jo01277a052

[45] Aiyelabola, T., Ojo, I., Adebajo, A., Ogunlusi, G., Oyetunji, O., Akinkunmi, E. and Adeoye, A. (2012) Synthesis Characterization and Antimicrobial Activities of Some Metal(II) Amino Acids' Complexes. Advances in Biological Chemistry, 2, 268-273. http://dx.doi.org/10.4236/abc.2012.23034

[46] Solis, P.N., Wright, C.W., Anderson, M.M., Gupta, M.P. and Phillipson, J.D. (1993) A Microwell Cytotoxicity Assay Using Artemia salina (Brine Shrimp). Planta Medica, 59, 250-252. https://doi.org/10.1055/s-2006-959661

[47] Pavia, D., Lampman, G. and Kriz, G. (2001) Introduction to Spectroscopy, A Guide for Students of Organic Chemistry. 3rd Edition, Thomson Learning, Boston, 22-368.

[48] Kemp, W. (1999) Organic Spectroscopy. 3rd Edition, Macmillan, Hong Kong, 19-98.

[49] Saunders, J.K.M. and Hunters, B.K. (1992) Modern NMR Spectroscopy a Guide for Chemists. 2nd Edition, Oxford University Press, London, 34-95.

[50] Hsiao, S., Chen, C. and Lou, G. (2004) Novel Aromatic Polyamiides Bearing Pendant diphenyllamino or Carbazolyl Groups. Journal of Polymer Science Part A: Polymer Chemistry, 42, 3302-3313. https://doi.org/10.1002/pola.20167

[51] Gunther, H. (1995) NMR Spectroscopy, Basic Principles, Concepts and Applications in Chemistry. 2nd Edition, John Wiley and Sons, New York, 1-78.

[52] Nakamoto, K. (2009) Infrared and Raman Spectroscopy of Inorganic and Coordination Compounds: Applications in Coordination, Organometallics and Bioinorganic Chemistry. 6th Edition, John Wiley and Sons, New York, 67-69. 
[53] Perkampus, H.-H. (1992) Analytical Application of UV-VIS Spectroscopy. In: Perkampus, H.-H., Ed., UV-VIS Spectroscopy and Its Applications, Springer Lab Manuals, Springer-Velag, Berlin, 26-80.

https://doi.org/10.1007/978-3-642-77477-5_4

[54] Bellamy, L.J. (1975) The Infrared Spectra of Complex Molecules. 1st Edition, Springer Netherlands, Dordrecht, 1-190.

[55] Stuart, B.H. (2004) Infrared Spectroscopy: Fundamentals and Applications. John Wiley and Sons Ltd., The Atrium, 1-110.

[56] Osowole, A.A., Kolawole, O.E. and Fagade, S. (2008) Synthesis Physicochemical and Biological Properties of Nickel(II), Copper(II) and Zinc(II) Complexes of an Unsymmetrical Tertradentate Schiff Base and Adducts with 2,2'-dipyridine and 1,10-phenantroline. Journal of Coordination Chemistry, 61, 1046-1055. https://doi.org/10.1080/00958970701482446

[57] Gaballa, A.S., Teleb, S.M., Asker, M.S., Yalçin, E. and Seferoğlu, Z. (2011) Synthesis and Spectroscopic Properties, and Aantimicroialacticities of Some New 5-phenylazo6-aminouracil-vanadyl Complexes. Journal of Coordination Chemistry, 64, 4225-4243. https://doi.org/10.1080/00958972.2011.637554

[58] Miessler, G.L. and Tarr, D.A. (1999) Inorganic Chemistry. Pearson Prentice Hall, New York, 315-316.

[59] Osowole, A. (2011) Synthesis, Characterization and Magnetic and Thermal Studies on Some Metal(II) Thiophenyl Schiff Base Complexes. International Journal of Inorganic Chemistry, 2011, Article ID: 650186.

[60] Youssef, N.S. and Hegab, K.H. (2005) Synthesis and Characterization of Some Transition Metal Complexes of Thiosemicarbazones Derived from 2-Acetylpyrrole and 2-Acetylfuran. Synthesis and Reactivity in Inorganic, Metal-Organic, and Nano-Metal Chemistry, 35, 391-399. https://doi.org/10.1081/SIM-200059215

[61] Raman, N., Pothiraj, K. and Baskaran, T. (2011) Synthesis, Characterization and DNA Damaging of Bivalent Metal Complexes Incorporating Dinitrogen-Dioxygen Ligand as Potential Biocidal Agent. Journal of Coordination Chemistry, 64, 4286-4330. https://doi.org/10.1080/00958972.2011.638979

[62] Aiyelabola, T.O., Akinkunmi, E., Ojo, I., Obuotor, E., Adebajo, C. and Isabirye, D. (2017) Syntheses, Characterization, Resolution and Biological Studies of Coordination Compounds of Aspartic Acid and Glycine. Bioinorganic Chemistry and Applications, 2017, Article ID: 2956145. https://doi.org/10.1155/2017/2956145

[63] Osowole, A.A. (2008) A Studies on Some VO(IV), Ni(II) and Cu(II) Complexes of Non-Symmetrical Tetradentat Schiff-Bases. Bulletin of the Chemical Society of Ethiopia, 22, 219-224. https://doi.org/10.4314/bcse.v22i2.61288

[64] Gómez, V., Vendier, L., Corbella, M. and Costes, J. (2011) Antiferromagnetic Co-Gd Interactions in a Tetranuclear $[\mathrm{CoGd}]_{2}$ Complex with Low-Spin Square-Planar Co Ions-Role of the Singly Occupied 3d Co Magnetic Orbital. European Journal of Inorganic Chemistry, 2011, 2653-2656. https://doi.org/10.1002/ejic.201100311

[65] Jaynes, B.S., Doerrer, L.H., Liu, S. and Lippard, S. (1995) Synthesis, Tuning of the Stereochemistry, and Physical Properties of Cobalt(II) Tropocoronand Complexes. Inorganic Chemistry, 34, 5735-5744. https://doi.org/10.1021/ic00127a010

[66] Anitha, C., Sheela, C.D., Tharmaraj, P. and Shanmugakala, R. (2013) Studies on Synthesis and Spectral Characterization of Some Transition Metal Complexes of Azo-Azomethine Derivative of Diaminomaleonitrile. International Journal of Inorganic Chemistry, 2013, Article ID: 436275. 
[67] Bu, X.R., Mintz, E.A., You, X.Z., Wang, R.X., Yue, Q., Meng, Q.J., Lu, Y.J. and Van Derveer, D. (1996) Synthesis and Characterization of Vanadyl Complexes with Unsymmetrical Bis-Schiff Base Ligands Containing a cis- $\mathrm{N}_{2} \mathrm{O}_{2}$ Coordinate Chromophore $^{1}$. Polyhedron, 15, 4585-4591. https://doi.org/10.1016/0277-5387(96)00220-3

[68] Syahmi, A., Vijayarathna, S., Sasidharan, S., Latha, L., Kwan, Y., Lau, Y., Shin L. and Chen, Y. (2010) Acute Oral Toxicity and Brine Shrimp Lethality of Elaeis guineensis Jacq., (Oil Palm Leaf) Methanol Extract. Molecules, 15, 8111-8121. https://doi.org/10.3390/molecules15118111

[69] Elsyana, V., Bintang, M. and Priosoeryanto, N. (2016) Cytotoxicity and Antiproliferative Activity Assay of Clove Mistletoe (Dendrophthoe pentandra (L.) Miq.) Leaves Extracts. Advances in Pharmacological and Pharmaceutical Sciences, 2016, Article ID: 3242698. https://doi.org/10.1155/2016/3242698

[70] Koch, S., Mayer, F., Honecker, F., Schittenhelm, M. and Bokemeyer, C (2003) Efficacy of Cytotoxic Agents Used in the Treatment of Testicular Germ Cell-Tumors under Normoxic and Hypoxic Conditions in Vitro. British Journal of Cancer, 89, 2133-2139. https://doi.org/10.1038/sj.bjc.6601375

[71] Rehman, S., Ikram, M., Rehman, S., Faiz, A. and Shah-nawaz, A. (2010) Synthesis, Characterization and Antim-Icrobial Studies of Transition Metal Complexes of Imidazole Derivative. Bulletin of the Chemical Society of Ethiopia, 24, 201-207. https://doi.org/10.4314/bcse.v24i2.54743

[72] Chohan, Z.H., Scozzafava, A. and Supuran, C.T. (2006) Synthesis of Biologically Active $\mathrm{Co}(\mathrm{II}), \mathrm{Cu}(\mathrm{II}), \mathrm{Ni}(\mathrm{II})$ and $\mathrm{Zn}(\mathrm{II})$ Complexes of Symmetrically 1,1'-Disubstituted Ferrocene Derived Compounds. Synthesis and Reactivity in Inorganic and Metal-Organic Chemistry, 33, 241-257. https://doi.org/10.1081/SIM-120017783

[73] Chohan, Z.H., Farooq, M.A., Scozzafava, A. and Supuran, C.T. (2002) Antibacterial Schiff Bases of Oxalyl-Hydrazine/Diamide Incorporating Pyrrolyl and Salicylyl Moieties and of Their Zinc(II) Complexes. Journal of Enzyme Inhibition and Medicinal Chemistry, 17, 1-7. https://doi.org/10.1080/14756360290005598

[74] Garba, S. and Salihu, L. (2011) Antibacterial Activities of 2-O-butyl-1-O-(2'-ethylhexyl) benzene-1,8-dicarboxylate and 1-phenyl-1,4-pentanedione Isolated from Vitellaria paradoxa Root Bark. Asian Journal of Scientific Research, 4, 149-157. https://dx.doi.org/10.3923/ajsr.2011.149.157

[75] Panchal, P.K., Parekh, H.M., Pansuriya, P.B. and Patel, M.N. (2006) Bactericidal Activity of Different Oxovanadium(IV) Complexes with Schiff Bases and Application of Chelation Theory. Journal of Enzyme Inhibition and Medicinal Chemistry, 21, 203-209. https://doi.org/10.1080/14756360500535229

[76] Srivastava, R.S. (2011) Pseudotetrahedral Co(II), Ni(II) and $\mathrm{Cu}(\mathrm{II})$ Complexes of $\mathrm{N}^{1}$-(O-chlorophenyl)-2-(2',4'-dihydroxyphenyl)-2-benzylazomethine Their Fungicidal and Herbicidal Activity. Inorganica Chimica Acta, 56, L65-L67. https://doi.org/10.1016/S0020-1693(00)88534-5

[77] Prakash, A. and Adhikari, D. (2011) Application of Schiff Bases and Their Metal Complexes-A Review. International Journal of Chem Tech Research, 3, 1891-1896.

[78] Walsh, C. (2003) Antibiotics: Action, Origin, Resistance. ASM Press, Washington DC, 1-335.

[79] Delica, K., Malik, M., Kerns, R.J. and Zhao, X.L. (2008) Quinolone Mediated Bacterial Death. Antimicrobial Agents and Chemotherapy, 52, 385-392. https://doi.org/10.1128/AAC.01617-06

[80] Floss, H.G. and Yu, T.W. (2005) Rifamycin-Mode of Action, Resistance and Biosynthesis. Chemical Reviews, 105, 621-632. https://doi.org/10.1021/cr030112j 